\title{
Associations between serum 25-hydroxyvitamin D, parathyroid hormone and osteocalcin in a representative sample of Irish adults aged $\geq 18$ years
}

\author{
S. Cassidy ${ }^{1}$, S. Muldowney ${ }^{1}$, E. Walsh ${ }^{1}$, J. Walton ${ }^{1}$, B. McNulty ${ }^{2}$, A. Nugent ${ }^{2}$, M. J. Gibney ${ }^{2}$, \\ A. Flynn ${ }^{1}$ and K. D. Cashman ${ }^{1}$ \\ ${ }^{1}$ School of Food and Nutritional Sciences, University College Cork, Cork, Republic of Ireland and ${ }^{2}$ Institute for Food and \\ Health, University College Dublin, Dublin, Republic of Ireland
}

The North American Institute of Medicine recently established new Dietary Reference Intakes for vitamin D based on its effects on bone health. Data on the association between serum 25-hydroxyvitamin D $(25(\mathrm{OH}) \mathrm{D}$; a marker of vitamin D status) and indices of Ca and bone metabolism in Ireland is limited to representative data in adolescents ${ }^{(1)}$ or data from convenience samples of adults ${ }^{(2,3)}$. The objective of this study was to examine the associations between serum $25(\mathrm{OH}) \mathrm{D}$, intact parathyroid hormone (iPTH) and osteocalcin (a marker of bone turnover) in a representative sample of Irish adults aged $\geq 18$ years.

Analysis was based on serum samples collected from participants of the recent National Adult Nutrition Survey (NANS) ( $n$ 1136; 575 men and 561 women) in Ireland. Serum 25(OH)D, PTH and osteocalcin concentrations were measured using ELISA methods.

There was an inverse relationship between serum $25(\mathrm{OH}) \mathrm{D}$ and iPTH $(R=-0.178 ; P<0.0001 ; n 1136)$ (see Figure). This association remained significant $(\beta=-0.004 ; P<0.0001)$ when potential confounders such as age, sex, fasting $v$. non-fasting serum sample were included in a regression model.

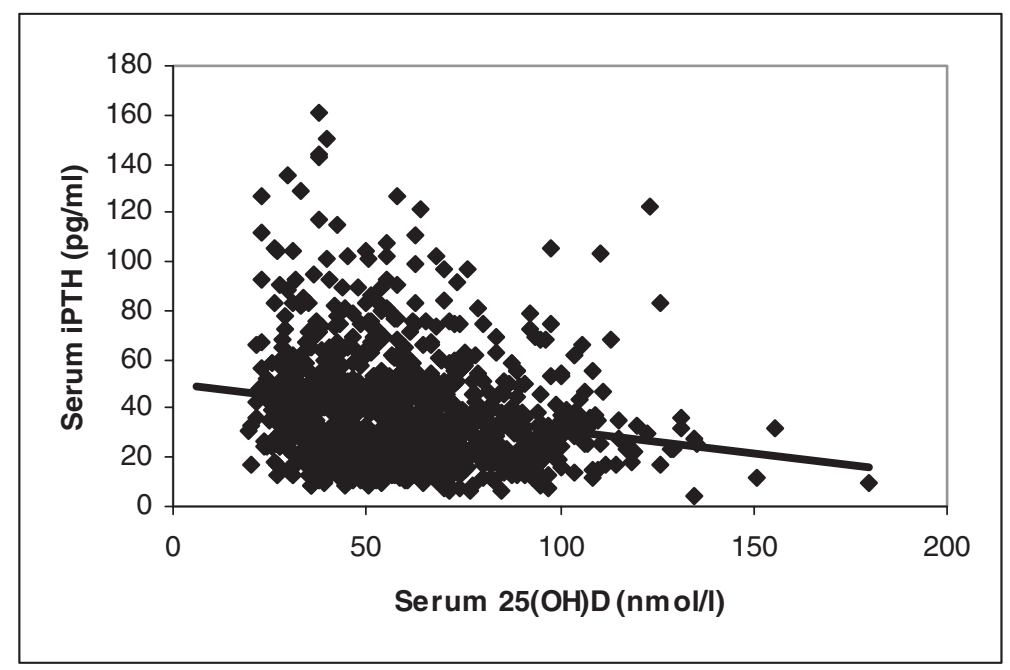

As an additional approach, we stratified the entire group by $<$ or $\geq 30,40,50,60,70,80 \mathrm{nmol} / 1$ serum $25(\mathrm{OH}) \mathrm{D}$ and compared mean serum iPTH concentrations in the resulting pair groups. There was a significant difference $(P<0.0001)$ between the $<$ or $\geq$ groups at all serum $25(\mathrm{OH}) \mathrm{D}$ thresholds, supporting a linear-type relationship with no apparent plateau. Serum osteocalcin was not associated with serum $25(\mathrm{OH}) \mathrm{D}$ or iPTH. However, when sex, age and fasting $v$. non-fasting serum sample were accounted for in a regression analysis, serum osteocalcin was positively associated with serum iPTH $(\beta=0.042 ; P=0.015)$.

In conclusion, these data show that serum iPTH was inversely associated with serum $25(\mathrm{OH}) \mathrm{D}$ in adults, which may have implications on the rate of bone turnover. Further research is warranted to explore the importance of these associations to bone health of the Irish adult population.

We wish to acknowledge the Irish Department of Agriculture, Fisheries and Food under the Food for Health Research Initiative (2007-2012) for their support.

1. Hill TR, Cotter AA, Mitchell S et al. (2010) Osteoporosis Int 4, 695-700.

2. Hill TR, O'Brien MM, Lamberg-Allardt C et al. (2006) Public Health Nutr 2, 225-233.

3. Lardner E, Fitzgibbon M, Wilson S et al. (2011) Ir J Med Sci 1, 115-119. 